\title{
Acute effects of gas supersaturation on Atlantic salmon smolt in two Norwegian rivers
}

\author{
Sondre Kvalsvik Stenberg 1 - Gaute Velle $\cdot$ Ulrich Pulg • Helge Skoglund
}

Received: 27 February 2020/Revised: 17 September 2020/ Accepted: 12 October 2020/Published online: 26 October 2020

(C) The Author(s) 2020

\begin{abstract}
Total dissolved gas (TDG) supersaturation downstream of hydropower plants may cause gas bubble disease (GBD) and harmful effects in fish. Little is known about tolerance levels of TDG supersaturation on Atlantic salmon (Salmo salar Linnaeus, 1758) in natural rivers. The present study investigated the effects of TDG supersaturation on the survival of Atlantic salmon smolts at two field sites in Norway. Here, we kept smolts in cages at increasing distances from hydropower plants known to cause TDG supersaturation and at control sites. We recorded fish mortality and examined for GBD using a stereo microscope. Mortality and symptoms of GBD commenced in fish exposed to an average of $108.3 \%$ TDG (maximum $111.0 \%$, water depth $0.55 \mathrm{~m}$ ) for 2 days. Significant differences in time before mortality at the
\end{abstract}

Guest editors: Ingeborg P. Helland, Michael Power, Eduardo G. Martins \& Knut Alfredsen / Perspectives on the environmental implications of sustainable hydropower

S. K. Stenberg $(\bowtie)$

Norwegian Institute for Water Research, Gaustadalléen 21, 0349 Oslo, Norway

e-mail: sondre.stenberg@niva.no

G. Velle · U. Pulg · H. Skoglund

Norwegian Research Centre, Nygårdsgaten 112,

5008 Bergen, Norway

G. Velle

Department of Biological Sciences, University of Bergen, Thormøhlensgate 53 A \& B, 5006 Bergen, Norway control sites and test sites commenced at $110.2 \%$ TDG (maximum $111.8 \%$ ) for 3 days. The study indicates that Atlantic salmon may be more vulnerable to TDG supersaturation than Pacific salmonids, which are considered at risk when the TDG is above $110 \%$. In addition, the study provides important data to link effects caused by TDG in the laboratory and in the field.

Keywords Hydropower - Total dissolved gas · Gas bubble disease $\cdot$ Bleke $\cdot$ Salmo salar $\cdot$ Supersaturation

\section{Introduction}

Both water pressure and temperature are often affected by river regulation and both these factors affect total dissolved gas (TDG). Gas supersaturation of water occurs when TDG pressure exceeds total atmospheric pressure at the water surface (i.e., total dissolved gas saturation $>100 \%$; Weitkamp, 2000). With increasing temperature, gas solubility decreases and TDG increases by approximately $2 \%$ per $1{ }^{\circ} \mathrm{C}$ in water (Marking, 1987). TDG is also affected by water pressure due to the increasing amount of gas that can be dissolved in water with increasing pressure and thus increasing depth (about $10 \%$ per m of water depth), according to Henry's law (Henry, 1803). Gas supersaturation can occur naturally in rivers, for example 
during rapid solar heating, algal blooms and downstream from waterfalls plunging into deep pools (Marking, 1987). It can also arise from human activity in at least two situations: (1) When air is entrained into the penstock system of hydropower plants (Heggberget, 1984; Pulg et al., 2016, Pulg et al., 2020) and (2) when air is entrained in plunge pools below dams (Ebel, 1969; Backman \& Evans, 2002; Weitkamp, 2008; Cao et al., 2019).

Supersaturation of TDG can be harmful to aquatic organisms (Nebeker, 1976; Bouck, 1980; Nebeker et al., 1981; Heggberget, 1984). In fish, the blood will become gas supersaturated when it respires in supersaturated water. When the blood is supersaturated, excess gas can form bubbles in the tissue (emphysema) and in the blood (emboli), which induces a variety of lethal and sub-lethal effects, often referred to as gas bubble disease (GBD; Bouck, 1980). The gas bubbles commonly occur in the gill blood vessels, eyes, mouth, organs, on the head and fins, along the lateral line, and some fish experience exophthalmia ("pop eyes"; Weitkamp \& Katz, 1980). The prevalence and severity of gas bubbles on external surfaces of fish may not be a good indicator to classify the extent of GBD (Mesa et al., 2000; Weitkamp, 2008). However, gas bubble formation on fins and gills indicate that the fish have harmful GBD (Weitkamp \& Katz, 1980; Mesa et al., 2000).

Research on tolerances to TDG has so far focused on fish species from China and North America. Several field- and laboratory studies on the impact of and tolerance to TDG on endemic fish species have been conducted during the recent years in China (Wang et al., 2015; Cao et al., 2019; Ji et al., 2019; Xue et al., 2019; Deng et al., 2020). These studies were conducted due to sharp declines in several endemic fish populations after construction of hydropower constructions, and indicate that the tolerance to TDG vary among fish species. Species-specific tolerance toward TDG has also been found for Pacific salmonids. Juvenile Chinook salmon (Oncorhynchus tshawytscha Walbaum, 1792) exposed to $130 \%$ TDG suffered $20 \%$ mortality after 3 to 6 h, while juvenile steelhead trout (Oncorhynchus mykiss Walbaum, 1792) suffered $20 \%$ mortality after 5 to $7 \mathrm{~h}$ (Mesa et al., 2000). At $110 \%$ TDG, juvenile steelhead trout may develop changes in blood chemistry (Newcomb, 1974), inflation of the gas bladder (Shrimpton et al., 1990) and bubbles on the caudal fin. Juvenile Chinook salmon can acquire acute GBD already at 106\% TDG with weakening of the swimming performance (Schiewe, 1974; Dawley \& Ebel, 1975). Other studies did not find acute effects at levels below $110 \%$ in Pacific salmonids (Krise \& Meade, 1988; Schisler et al., 1999; Geist et al., 2013; Brosnan et al., 2016).

Atlantic salmon (Salmo salar Linnaeus, 1758) naturally lives in about 2000 rivers that drain into the North Atlantic Ocean (MacCrimmon \& Gots, 1979). During the past two decades, the total number of wild Atlantic salmon has declined dramatically, and several populations are now extinct (Anon, 2018; Mills et al., 2013). Relatively few studies have investigated effects of TDG supersaturation in Atlantic salmon, despite its distribution in rivers that are often exploited for hydropower purpose. In a laboratory study with $15 \mathrm{~cm}$ deep tanks, sub-yearling Atlantic salmon were less tolerant to TDG than lake trout (Salvelinus namaycush Walbaum, 1792) (Krise \& Herman, 1991). Here, Atlantic salmon mortality commenced from 114\% TDG, and 50\% mortality occurred after $96 \mathrm{~h}$ at $117 \%$ TDG for parr (mean length $14.8 \mathrm{~cm}$ ) and 118 to $122 \%$ for smaller parr and fry $(6.6-2.3 \mathrm{~cm})$. Other studies on gas supersaturation in Atlantic salmon have focused on oxygen (not total gas) saturation (Espmark et al., 2010; Kristensen et al., 2010). Espmark et al. (2010) observed gas bubbles in Atlantic salmon smolts exposed to water supersaturated with $160 \%$ oxygen for 14 days. However, salmonids (e.g., Atlantic salmon) exposed to water supersaturated with oxygen develop gas bubbles at higher supersaturation than in water supersaturated with atmospheric gas (Nebeker et al., 1976; Espmark et al., 2010). In Atlantic salmon hatcheries, production problems may commence from 104 to $105 \%$ TDG (Marking, 1987). These results suggest that Atlantic salmon is particularly sensitive to TDG supersaturation among salmonids. Potential harmful levels of TDG can occur in rivers with Atlantic salmon several $\mathrm{km}$ downstream from hydroelectric installations and dams (Heggberget, 1984; Pulg et al., 2016; Pulg et al., 2020). However, detailed knowledge on effects and tolerances of TDG in Atlantic salmon and most other species of fish are lacking. The difference in tolerance toward TDG among salmonids raises questions whether sensitive species are affected at a lower level than previously thought. Species-specific tolerance to TDG should therefore be known when setting criteria in natural settings for maximum TDG levels. 
The aim of this study was to identify the effects of TDG supersaturation exposure on Atlantic salmon in controlled field settings. We placed fish in cages with varying distance from the source of TDG supersaturation (i.e., hydropower plants) in two Norwegian rivers, and thereby exposed fish to varying levels of TDG. Such information is necessary to link the results of laboratory experiments to conditions in the natural habitat, to set thresholds for acceptable levels of TDG and to conduct mitigation measures. In both rivers, the public and environmental protection agencies were concerned for potential harmful effects on fish due to TDG supersaturation.

\section{Materials and methods}

Study sites

River Otra is situated in southern Norway and has a catchment area of about $4000 \mathrm{~km}^{2}$ and an average discharge of $150 \mathrm{~m}^{3} \mathrm{~s}^{-1}$ at the river mouth (Fig. 1). The upper part of River Otra, where this study was conducted, has a relict population of the landlocked Atlantic salmon commonly referred to as "Bleke" (Salmo salar ssp.) (Wright et al., 2016). Hydropower has been extensively developed in the River Otra (Fig. 1). Brokke power plant is a reservoir hydropower plant with 13 secondary creek intakes, has a head (vertical height between intake and discharge point) of $300 \mathrm{~m}$ and produces a maximum of $330 \mathrm{MW}$ at four Francis wheels. The inlet of Hekni power plant is located $11 \mathrm{~km}$ downstream of Brokke power plant. Hekni is a run-of-the-river hydropower plant with a head of $38.5 \mathrm{~m}$ and a maximum power of $56 \mathrm{MW}$ at two Kaplan wheels, bypassing water over a stretch of 8 $\mathrm{km}$ in the main river (Fig. 1).

Lake Evangervatnet is a part of the Vosso watercourse in Western Norway (Fig. 2). The Vosso River has a catchment area of about $1500 \mathrm{~km}^{2}$ with an average discharge of $108 \mathrm{~m}^{3} \mathrm{~s}^{-1}$ at the river mouth. The Atlantic salmon population in the Vosso collapsed in the late 1980s (Barlaup et al., 2018). Since then, intensive abatement measures, such as restocking, have been carried out to restore the population. However, significant stressors for the fish population are still present, such as salmon lice, competition and introgression with escaped farmed Atlantic salmon and hydropower. The Evanger power plant, approximately $7 \mathrm{~km}$ upstream from the river mouth, is a reservoir hydropower plant with a head of $770 \mathrm{~m}$ and a maximum power yield of $330 \mathrm{MW}$ at three Pelton wheels.

\section{Cages}

The study was conducted by exposing juvenile Atlantic salmon to supersaturated water in cages. Two cages were placed at each of the five study sites in River Otra at 0.1 to $0.55 \mathrm{~m}$ water depth (cage type: length $0.45 \mathrm{~m}$, width $0.35 \mathrm{~m}$, height $0.45 \mathrm{~m}$ ). The depths reflect the typical habitat of juvenile Bleke in this river stretch. Stones were placed in the cages and acted as bottom weight and shelter for the fish. The site Brokke $+0 \mathrm{~km}$ was placed at the outlet of Brokke power plant, and the remaining sites were placed at increasing distance downstream: Brokke $+17.5 \mathrm{~km}$ (downstream the outlet of Hekni power plant), Brokke $+21 \mathrm{~km}$ and Brokke $+30 \mathrm{~km}$ (Fig. 1). The last cage was placed $11 \mathrm{~km}$ downstream of Brokke (Brokke $+11 \mathrm{~km}$ ) in a residual flow reach between the Tjurrmo dam and Hekni power station. The residual flow reach has a lower discharge (minimum $5 \mathrm{~m}^{3} \mathrm{~s}^{-1}$ ) than upstream of the dam, and the water is well aerated as it passes the dam. This site has low levels of supersaturation and acted as control.

In Lake Evangervatnet, two cages were placed at 0 to $1.15 \mathrm{~m}$ depth at four sites with different distances to the Evanger power plant (cage type: radius $0.32 \mathrm{~m}$, height $1.15 \mathrm{~m}$ ). The depth distribution reflects the typical depth distribution of juvenile salmon in such lakes, including out-migrating smolts. Cages were placed at three sites downstream of the power plant (Evanger $+0 \mathrm{~km}$, Evanger $+0.5 \mathrm{~km}$, Evanger +5.4 $\mathrm{km}$; Fig. 2) and at one control site upstream of Evanger power plant (Evanger $-1.4 \mathrm{~km}$ ).

Fish

10 Atlantic salmon smolts (wild Bleke strain hatched and reared at Syrtveit hatchery, average length 12.6 $\mathrm{cm}$, average weight $18.7 \mathrm{~g}$ ) were placed in each cage in River Otra and 15 Atlantic salmon smolts (wild Vosso strain hatched and reared at Voss hatchery, average length $13.2 \mathrm{~cm}$, average weight $21.2 \mathrm{~g}$ ) were placed in each cage in Lake Evangervatnet. The fish could feed on naturally drifting invertebrates passing though the cages during the exposure period, and were not fed. 


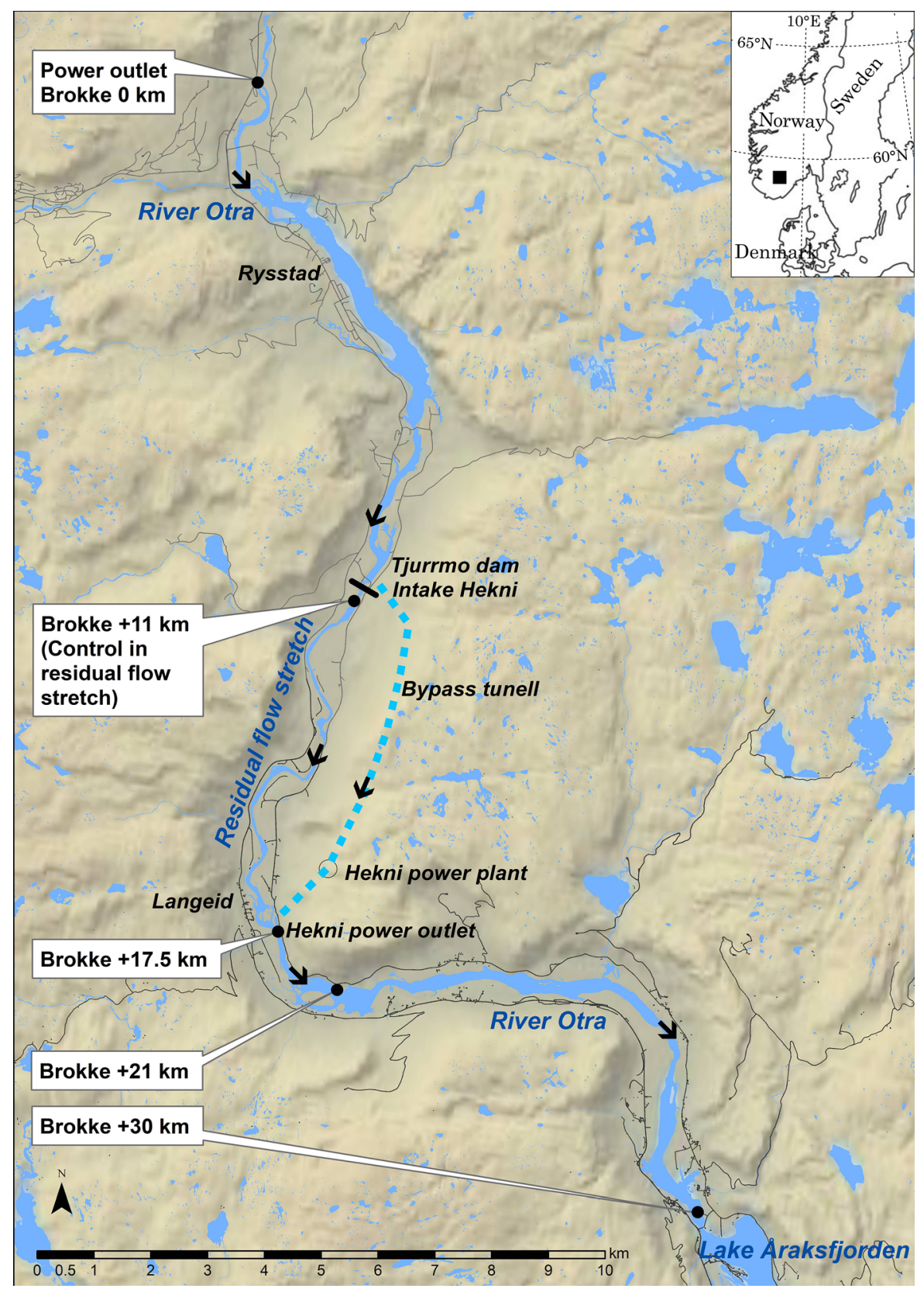

Fig. 1 River Otra, southern Norway, indicating Brokke- and Hekni hydropower plants, and the study sites (black dots) at Brokke $+0 \mathrm{~km}$, Brokke $+11 \mathrm{~km}$ (control site), Brokke +17.5

The experiments were conducted with permission from the animal experimentation administration of the Norwegian Food Safety Authority (Permission nos. $16 / 86290$ and 16-20221). $\mathrm{km}$, Brokke $+21 \mathrm{~km}$ and Brokke $+30 \mathrm{~km}$. Arrows indicate the direction of the water current

Exposure period and fish examination

The experiment took place between June 6 and June 14, 2016 in River Otra. Here, the smolts were sampled and examined after 3 and 8 days of exposure, except at Brokke $+0 \mathrm{~km}$ where one fish was sampled after 1.5, 


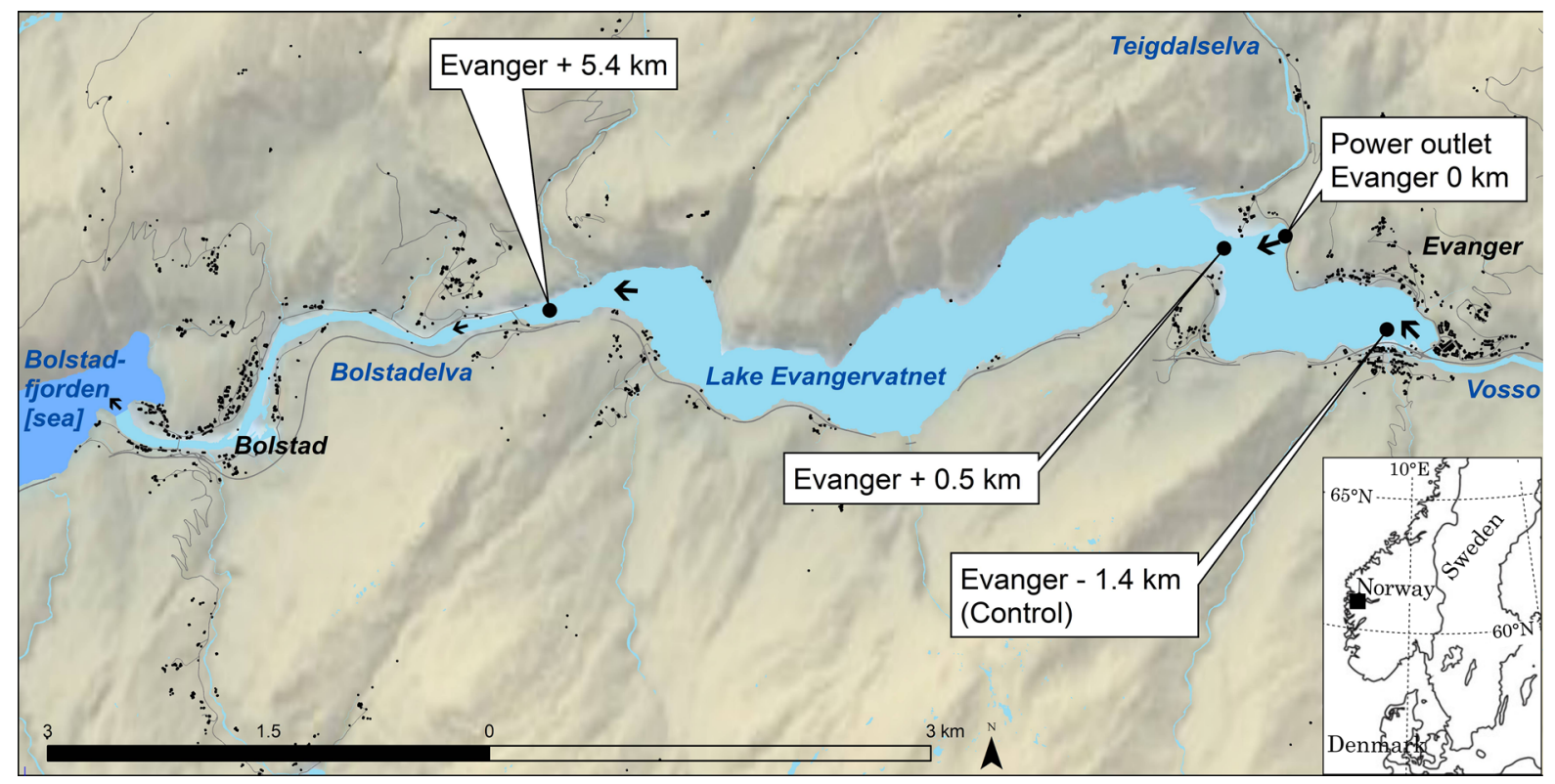

Fig. 2 Lake Evangervatnet in the Vosso River, western Norway, indicating the outlet of Evanger Power Plant and the study sites (black dots) at Evanger $-1.4 \mathrm{~km}$ (control site),

2, 3, and $4 \mathrm{~h}$ and the remaining fish were sampled after $12 \mathrm{~h}$ to ensure fish welfare since the fish experienced acute mortality. For animal welfare reasons, the number of fish at the start of the exposure at Brokke +0 was still similar to the other sites. At the other sites in River Otra and Lake Evangervatnet, five fish from all cages were examined at each sampling until there were no fish left or until the termination date when the remaining fish were killed and examined. In Lake Evangervatnet, the experiment took place between May 10 and May 24 2016. The smolts from Lake Evangervatnet were sampled and examined after 4 and 14 days of exposure.

Daily inspections of the fish were conducted at all sites to record potential mortality. Inspections were done by a person wearing dive mask and snorkel that carefully approached the cages. Fish sampled for examination were netted with a knot free dip net and into a bucket with water from the site. Alive fish were euthanized with clove oil, while dead fish were placed in a separate bucked without clove oil. Immediately subsequent to death, the lateral line, the fins, the eyes and all the gill arches were carefully inspected for bubbles using a stereo microscope and 25 to $50 \times$ magnification. The eyes were also examined for pop eyes or exophthalmia. During examination, the gill
Evanger $+0 \mathrm{~km}$, Evanger $+0.5 \mathrm{~km}$ and Evanger $+5.4 \mathrm{~km}$. Arrows indicate the direction of the water current

arches were removed from the fish and bathed in water from the site.

\section{TDG monitoring}

TDG was measured at every $10 \mathrm{~min}$ for each site in River Otra (1 min increments at Brokke $+0 \mathrm{~km})$ and for every $20 \mathrm{~min}$ in Lake Evangervatnet. TDG was monitored by a Total Gas Analyzer 3.0 (Fisch- und. Wassertechnik; Pulg et al., 2016), which is based on the Weiss-saturometer principle (Weiss, 1970). A Total Gas Analyzer measures TDG pressure in a submerged gas permeable silicon hose connected to a pressure sensor and an atmospheric pressure sensor, which is at the water surface. The saturation is measured as the percent dissolvable air in the surface water ( $0 \mathrm{~m}$ depth) at the prevalent air pressure, and the saturometer has an accuracy of $\pm 10 \mathrm{hPa}$, which is approximately $\pm 1 \%$ TDG (pers. comm., manufacturer). We used new saturometers and atmospheric pressure sensors that were pre calibrated by the manufacturer in April 2016 at 1000 and $2000 \mathrm{hPa}$ (approx. 100 and $200 \%$ TDG at sea level). The dry saturometer pressure sensors were re-calibrated in the field 1 day prior to the onset of the experiment by synchronizing them to the atmospheric pressure 
sensors. The saturometers were placed at $40 \mathrm{~cm}$ depth at the test sites. To avoid bubble formation in the silastic tubing of the saturometer, we knocked on the probes for a few minutes after submergence and ensured continuous water flow over the probes during the study to remove potential bubbles.

\section{Numerical analyses}

The fish survival distribution was tested using a Kaplan-Meier survival log-rank test (Kaplan \& Meier, 1958). First, the survival curves were compared among sites. The log-rank test assumes that all survival time data is equally accurate, and the survival curves were considered statistically significant when $P<0.001$. Second, we performed a pairwise multiple comparison analysis (Holm-Sidak method) to correct the $P$-value for multiple testing when the survival curves showed a significant difference among survival curves $(P<0.05)$ (Holm, 1979). The survival analysis was performed using Sigmaplot (version 13.0).

\section{Results}

\section{Observed TDG levels}

Average TDG varied from 105.5 to $111.6 \%$ and 105.6 to $107.2 \%$ in the River Otra and Lake Evangervatnet, respectively (Table 1). TDG saturation at Brokke +0 $\mathrm{km}$ showed the highest maximum and average TDG. All sites in the River Otra had decreasing average and maximum TDG with increasing distance $(0-30 \mathrm{~km})$ from the power plant outlet, expect at the control site (Fig. 3). At Lake Evangervatnet, the average TDG supersaturation was relatively similar among the test sites (Fig. 4; Table 1). Here, the highest maximum TDG supersaturation occurred at Evanger $+0.5 \mathrm{~km}$ (112.8\% TDG) (Fig. 4). The lowest average and maximum TDG were measured at the control site in both rivers (Table 1).

TDG saturation at both study sites showed a diurnal pattern with lowest TDG in the morning until noon and with increasing TDG saturation during the evening (Figs. 3 and 4). In addition, the average TDG in River Otra was higher during the first 3 days of the experiment than during the last 5 days (Table 1). There were no temporal differences in TDG levels in
Lake Evangervatnet during the exposure period (Fig. 4).

Mortality

No Atlantic salmon died at the control site in the River Otra (Brokke $+11 \mathrm{~km})$ during the 8 days of exposure. Here, the average TDG of the surface water was $105.5 \%$ (Table 1). The mortality probability at Brokke $+30 \mathrm{~km}$ and Brokke $+21 \mathrm{~km}$ were relatively small (10 and 25\%, respectively), and the time until mortality was not significantly different than at the control site (Table 2; Fig. 3). First mortality at Brokke $+21 \mathrm{~km}$ occurred after 3 days of exposure at an average TDG of $108.3 \%$ (111.0\% TDG maximum). While at Brokke $+30 \mathrm{~km}$, first mortality occurred after 2 days of exposure at an average TDG of $109.6 \%$ (111.6\% TDG maximum) (Table 1; Fig. 3).

There was a significantly different mortality time at Brokke $+17.5 \mathrm{~km}$ compared to the control site and Brokke $+30 \mathrm{~km}$ (Table 2). The salmon at Brokke + $17.5 \mathrm{~km}$ had a mortality probability of $55 \%$ after 3 days exposure at an average and maximum TDG of 110.2 and $111.8 \%$, respectively (Table 1 ).

The mortality probability at Brokke $+0 \mathrm{~km}$ was $81 \%$ after $12 \mathrm{~h}$ exposure at an average and maximum TDG of 111.6 and $114.3 \%$, respectively. Time to mortality was significantly faster at Brokke $+0 \mathrm{~km}$ than at the other sites (Table 2; Fig. 3).

We observed no mortality at the test sites in Lake Evangervatnet after 4 days or 14 days of exposure at an average TDG of 105.6 to $107.2 \%$ (Table 1; Fig. 4).

Gas bubble disease

We found gas bubbles on the fins and gills indicating GBD in fish at all study sites in River Otra, except at the control site (Table 1). No pop eyes or bubbles in the lateral line were observed. Of the fish sampled alive ( $n=64), 22 \%$ had signs of GBD (Fig. 5). Of the fish sampled subsequent to death, $76 \%$ had bubbles on the caudal- and anal fins (Table 1). The first gas bubbles were observed after $12 \mathrm{~h}$ of exposure at Brokke $+0 \mathrm{~km}$. Of the salmon sampled alive after 8 days of exposure at the sites Brokke $+11 \mathrm{~km}$, Brokke $+21 \mathrm{~km}$ and Brokke $+30 \mathrm{~km}$, we found gas bubbles only in fish from Brokke $+21 \mathrm{~km}$. No fish in the Lake Evangervatnet had signs of GBD (Table 1). 


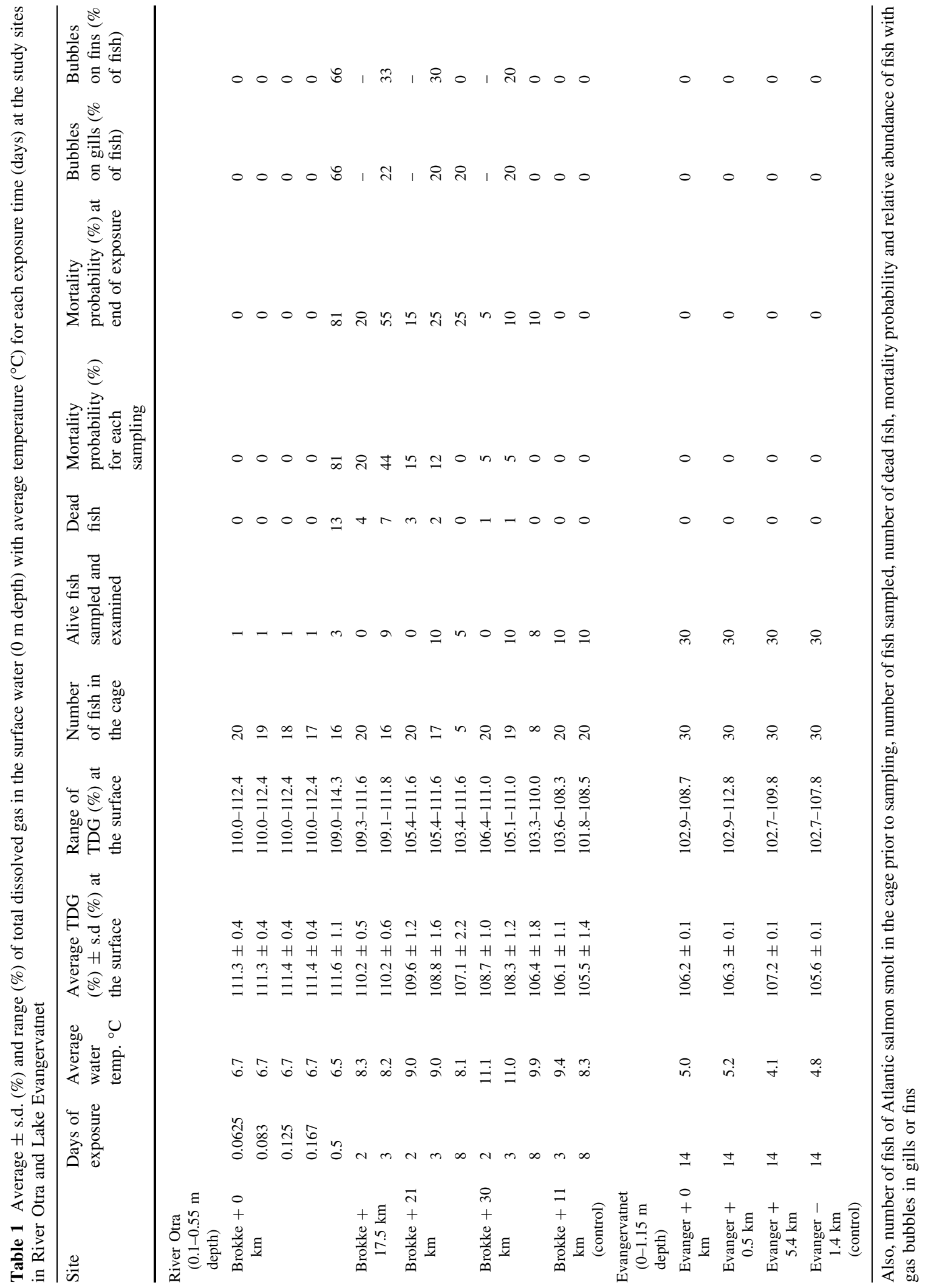




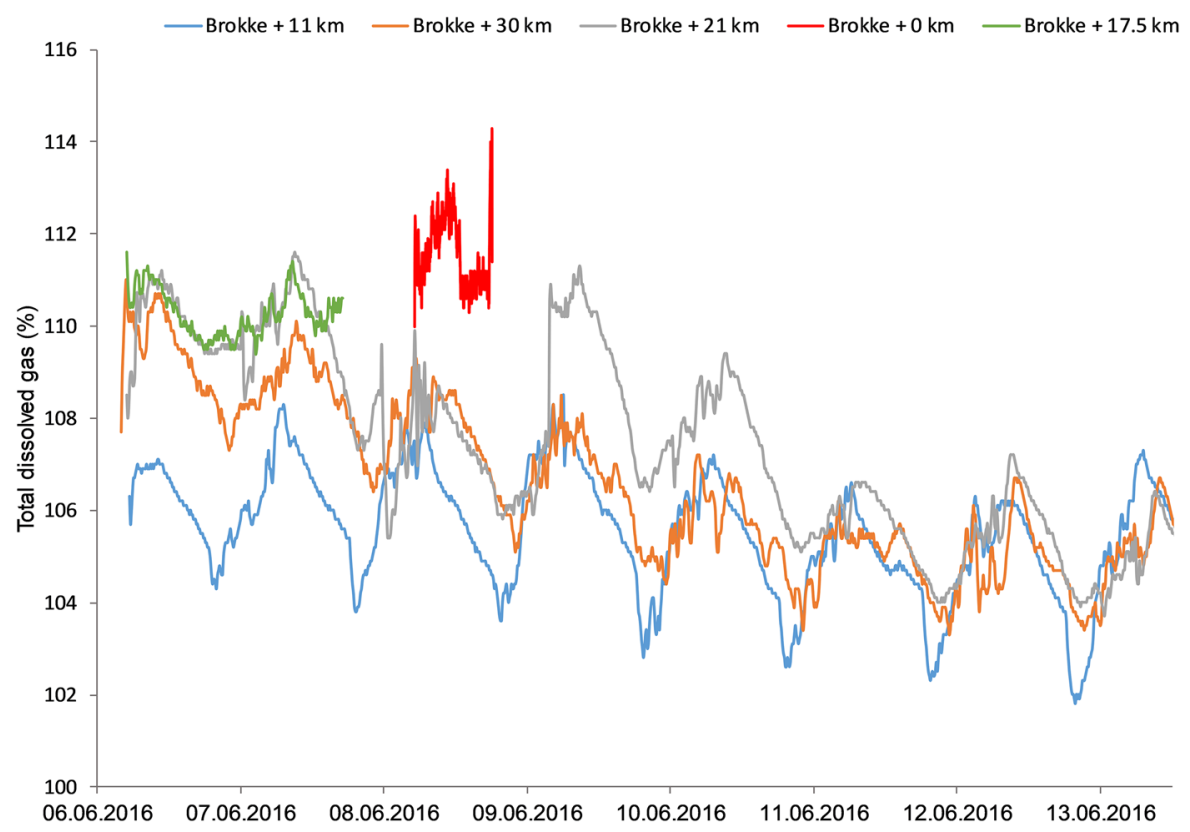

Fig. 3 Total dissolved gas $(\%)$ in the surface water $(0 \mathrm{~m}$ depth $)$ at the study sites (Brokke $+0 \mathrm{~km}($ control $)$, Brokke $+11 \mathrm{~km}, \mathrm{Brokke}+$ $17.5 \mathrm{~km}$, Brokke $+21 \mathrm{~km}$ and Brokke $+30 \mathrm{~km}$ ) during the exposure period in River Otra

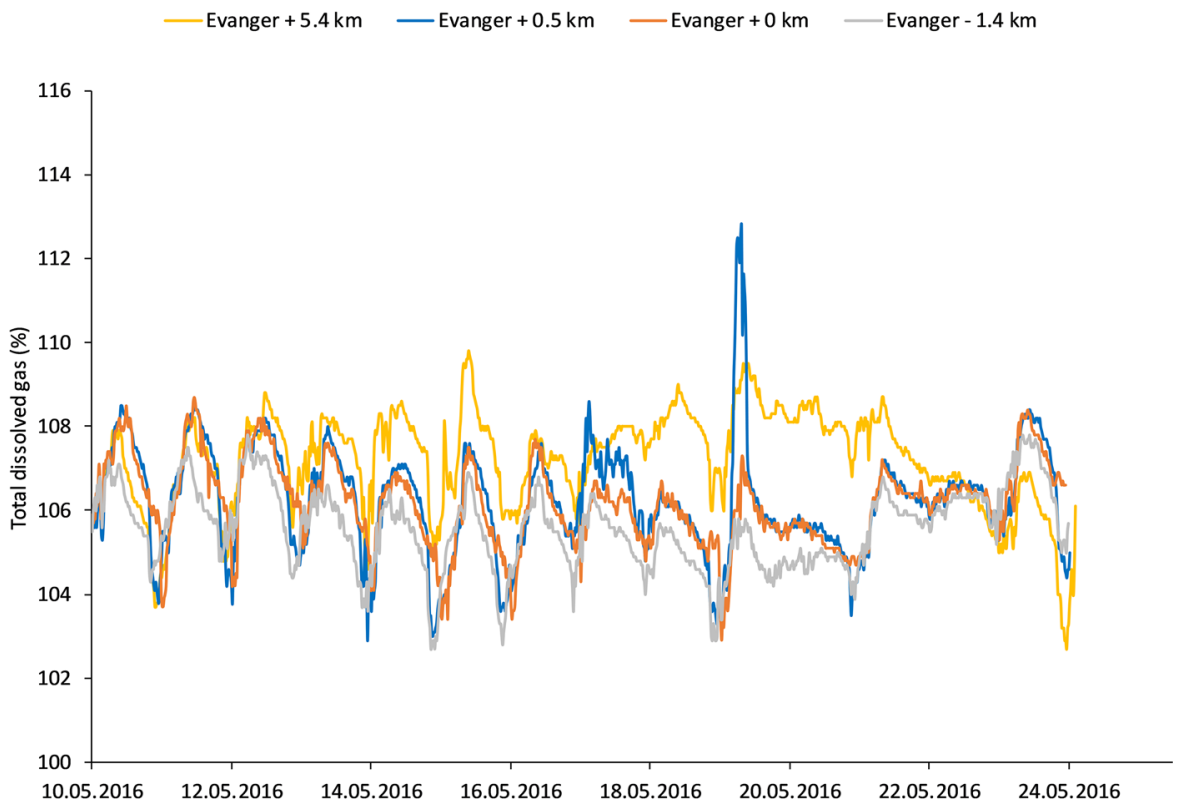

Fig. 4 Total dissolved gas $(\%)$ in the surface water $(0 \mathrm{~m}$ depth) at the study sites (Evanger $-1.4 \mathrm{~km}$ (control), Evanger $+0 \mathrm{~km}$, Evanger $+0.5 \mathrm{~km}$ and Evanger $+5.4 \mathrm{~km})$ during the exposure period in Lake Evangervatnet 
Table 2 Comparison of mortality of Atlantic salmon smolts among the sites Brokke $+0 \mathrm{~km}$, Brokke $+11 \mathrm{~km}$, Brokke 17.5 $\mathrm{km}$, Brokke $+21 \mathrm{~km}$ and Brokke $+30 \mathrm{~km}$

\begin{tabular}{lrr}
\hline Comparison & \multicolumn{1}{l}{ t } \\
\hline Brokke $+17.5 \mathrm{~km}$ vs. Brokke $+0 \mathrm{~km}$ & 24.728 & $<0.01$ \\
Brokke $+21 \mathrm{~km}$ vs. Brokke $+0 \mathrm{~km}$ & 24.728 & $<0.01$ \\
Brokke $+30 \mathrm{~km}$ vs. Brokke $+0 \mathrm{~km}$ & 24.728 & $<0.01$ \\
Brokke $+11 \mathrm{~km}$ vs. Brokke $+0 \mathrm{~km}$ & 24.728 & $<0.01$ \\
Brokke $+17.5 \mathrm{~km}$ vs. Brokke $+11 \mathrm{~km}$ & 14.725 & $<0.01$ \\
Brokke $+30 \mathrm{~km}$ vs. Brokke $+17.5 \mathrm{~km}$ & 8.692 & 0.016 \\
Brokke $+21 \mathrm{~km}$ vs. Brokke $+11 \mathrm{~km}$ & 5.577 & 0.071 \\
Brokke $+21 \mathrm{~km}$ vs. Brokke $+17.5 \mathrm{~km}$ & 3.106 & 0.216 \\
Brokke $+30 \mathrm{~km}$ vs. Brokke $+11 \mathrm{~km}$ & 2.052 & 0.281 \\
Brokke $+30 \mathrm{~km}$ vs. Brokke $+21 \mathrm{~km}$ & 1.540 & 0.215 \\
\hline
\end{tabular}

The overall significance level was 0.05

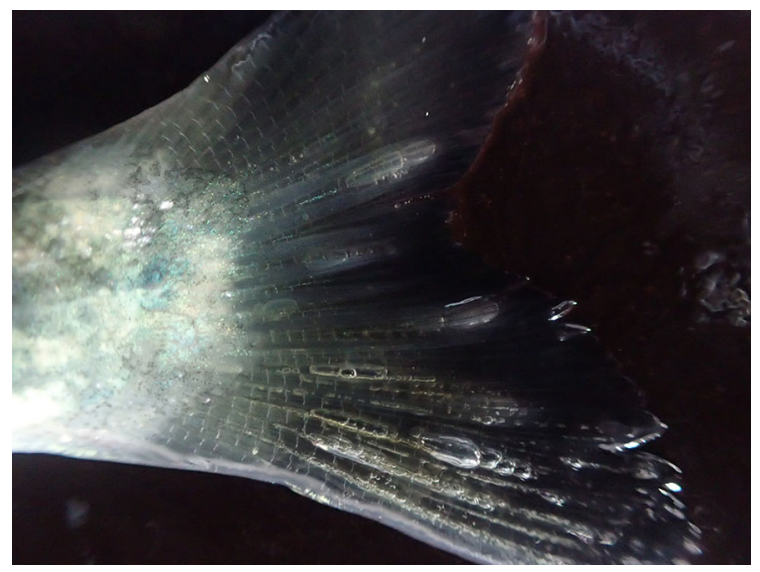

Fig. 5 A caudal fin of an Atlantic salmon (S. salar ssp. Bleke) with gas bubbles. The fish was held for 3 days at Brokke +30 $\mathrm{km}$ in River Otra

\section{Discussion}

No mortality was observed in the Evangervatnet trials. In the River Otra trials, however, GBD and mortality occurred. The mortality probability was larger than $50 \%$ after exposure to an average of $110.2 \%$ TDG (maximum of $111.8 \%$ ) for 3 days in the River Otra. The lowest average TDG level at which mortality occurred was $108.3 \%$ TDG (maximum of $111 \%$ ). We observed that fish mainly used the lower part (ca. 0.3-0.55 m depth) of the cages in the River Otra and middle part (ca. 0.3-0.9 m depth) of the cages in the Lake Evangervatnet. When compensating for pressure
(Pleizier et al., 2020), an average TDG of 110.2 and $108.3 \%$ in the surface water provides compensation to ca 107 and $105 \%$ TDG at $0.3 \mathrm{~m}$ water depth and 105 and $103 \%$ TDG at $0.9 \mathrm{~m}$ depth at the bottom of the cages. In the Lake Evangervatnet, an average TDG of $107.2 \%$ did not cause mortality. A TDG of $107.2 \%$ at the water surface provide compensation to 104 and 98\% TDG at $0.3 \mathrm{~m}$ and $0.9 \mathrm{~m}$ water depths, respectively. Thus, the higher mortality in Otra than at Evanger can be explained by the higher TDG levels in Otra and better depth compensation in Evanger. After compensating for depth, the results indicate a gradually increasing risk of GBD in Atlantic salmon smolt above $105 \%$ TDG.

Tolerance toward TDG differs among species (Mesa et al., 2000) and life stages (Geist et al., 2013). Most studies of Pacific salmonids indicate increased mortality and GBD above $115 \%$ TDG (Weitkamp, 2008; Geist et al., 2013; Brosnan et al., 2016). Several studies have also found GBD and mortality at lower TDG than $115 \%$. Mesa et al. (2000), Antcliffe et al. (2002) and Dawley \& Ebel (1975) showed that gas bubbles in juvenile Chinook salmon and rainbow trout (Oncorhynchus mykiss Walbaum, 1792) can occur from about $106 \%$ to $110 \%$ TDG, which corresponds to our results. In addition, salmonids have shown low mortality rate $(0.0-3.3 \%)$ at $106 \%$ TDG in $25 \mathrm{~cm}$ deep tanks for 35 days (Dawley \& Ebel, 1975). In contrast to our results, previous studies on salmonids found no significant mortality at 110\% TDG (Newcomb, 1974; Mesa et al., 2000; Antcliffe et al., 2002) and TDG levels up to ca. $110 \%$ are referred to as "chronic" or "sub-lethal" for Pacific salmonids, while increasing levels may result in acute GBD (Alderdice \& Jensen, 1985; Antcliffe et al., 2002). When compensating for depth, the threshold from which GBD commenced in Atlantic salmon in our study was approximately $2 \%$ lower than the threshold for Pacific salmonids (Alderdice \& Jensen, 1985; Antcliffe et al., 2002). This may indicate a higher vulnerability of Atlantic salmon.

In a study where Atlantic salmon was exposed to TDG supersaturation at $15 \mathrm{~cm}$ water depth in laboratory settings, acute mortality occurred from $117 \%$ TDG and no mortality occurred at $\leq 110 \%$ TDG (Krise \& Herman, 1991). There are at least six factors that may explain differences in mortality between our study and the study by Krise \& Herman (1991). These factors may to some extent also be valid for other 
studies that find different susceptibility toward TDG supersaturation for single species. (1) The Atlantic salmon in River Otra is a relict landlocked population, whereas the Atlantic salmon from Lake Evangervatnet and in the laboratory study (Krise \& Herman (1991) are anadromous populations. Although the landlocked and anadromous populations constitute the same species, physiological differences could potentially have formed over the 9000 years since the populations were separated (Hutchings et al., 2019). For example, the landlocked population smoltifies, but not to the same extent as anadromous salmon that undergo more extensive physiological adaptations to increased salinity. Therefore, we cannot rule out that the Bleke strain from River Otra is more vulnerable to TDG than other populations of Atlantic salmon. (2) Divergent results among studies can potentially be attributed to differing sensitivity toward TDG among populations, life stages and individuals of the same species (Weitkamp \& Katz, 1980; Mesa et al., 2000). For example, Meekin \& Turner (1974) found 8 to $100 \%$ mortality among groups of juvenile Chinook salmon exposed to $114 \%$ TDG for 6 days in tanks with $20 \mathrm{~cm}$ water depth. (3) In contrast to the laboratory study by Krise \& Herman (1991) with a fixed TDG concentration in the laboratory, there were fluctuating levels of TDG in our field study. These levels varied according to the production at the power stations and according to natural levels of water discharge. Brosnan et al. (2016) found that Chinook salmon smolts exposed periodically to an average of $132 \%$ TDG and chronic exposure to an average of $118 \%$ TDG had increased mortality compared to smolts exposed to only chronic $118 \%$ TDG. This suggests that multiple exposure to TDG supersaturated water can cause increased mortality. (4) The fish in our study were reared in hatcheries that have been operating for more than two decades without signs of GBD. Thus, TDG was not measured at the hatcheries prior to the study. However, if the fish were exposed to unknown supersaturated water prior the study, this could potentially cause an increased susceptibility to TDG. (5) Fish in the field may be more sensitive to TDG than fish in controlled laboratory settings. For example, stress caused by translocation to the field, diseases, potential predators, lack of food and water current in the field may induce increased sensitivity. (6) As in most field studies, limited sampling interval, number of fish, and measure accuracy ( $\pm 1 \%$ TDG) may influence the results. The results must be set into a larger context, preferably a meta-study, before generalizing.

The preference for depth varies among fish species and life stages. For example, radio tagged rainbow trout, cutthroat trout (O. clarkii Richardson, 1836), brown trout (Salmo trutta Linnaeus, 1758) and bull trout (Salvelinus confluentus Suckley, 1859) occupy median depths from 1.3 to $2 \mathrm{~m}$ in a river with $101 \%$ to 135\% TDG (Weitkamp \& Sullivan, 2003). The depth preference for fish is important because hydrostatic pressure protects fish from GBD by ca $10 \%$ per meter depth (Pleizier et al., 2020). Fish can compensate by swimming deeper, thereby reducing harmful effects from TDG compared to fish confined to shallow water (Ebel, 1969; Weitkamp, 1976; Heggberget, 1984; Cao et al., 2019; Pleizier et al., 2020). This was demonstrated by Antcliffe et al. (2002), who exposed juvenile rainbow trout to $122 \%$ TDG for $96 \mathrm{~h}$ in tanks of differing water depth. They found no mortality at 0 to $2.5 \mathrm{~m}$ depth, $22 \%$ mortality at 0 to $1 \mathrm{~m}$ depth and $90 \%$ mortality at 0 to $0.25 \mathrm{~m}$ depth. Field studies have also shown that the survival of fish exposed to TDG supersaturation is influenced by available depth (Cao et al., 2019; Heggberget, 1984). Brown trout, perch (Perca fluviatilis Linnaeus, 1758) and eel (Anguilla Anguilla Linnaeus, 1758) held in cages near the surface showed signs of GBD and higher mortality compared to fish at greater depth (Heggberget, 1984). Based on these findings, Heggberget (1984) concluded that resident fish that can occupy deeper water are less likely to suffer mortality from nitrogen supersaturation (100-200\% $\mathrm{N}_{2}$ ). Therefore, results from the current study are relevant for fish that occupy the shallow areas of the watercourse, which are the preferred habitat for juvenile Atlantic salmon. In addition, the results are relevant for salmon that occupy deeper parts and occasionally spend time closer to the surface. Even brief periods spent close to surface can cause GBD due to the combination of lower hydrostatic pressure at shallower depths and the effects of decompression (Weitkamp, 2008).

Some countries have national TDG guidelines to protect aquatic organisms. The US Environmental Protection Agency (EPA) enforces a TDG threshold at $110 \%$ TDG (USEPA, 1976). Despite the TDG criteria in the EPA guidelines, each US state can include exemptions to the guidelines with its own regulations (ex. maximum up to $125 \%$ TDG in Oregon). In Canada, the Canadian Council of Ministers of the 
Environment (1999) recommend a maximum of $103 \%$ TDG for shallow water less than $1 \mathrm{~m}$ deep. Similar to the US, each province in Canada have separate TDG regulations. However, most countries lack TDG criteria for aquatic organisms. Future research should focus on five key themes to set robust management criteria for Atlantic salmon: (1) find critical TDG levels for mortality and sub-lethal effects for all life stages of Atlantic salmon, (2) examine the depth distribution and avoidance behavior of Atlantic salmon in areas with TDG supersaturation, (3) examine effects caused by repeated exposure, (4) examine stress-on-stress effects and (5) examine effects on biological production, including fish and benthic invertebrates.

Acknowledgements We thank Braun, M. and Handl, J. for help during the field work, and the Voss klekkeri and Syrtveit Fiskeanlegg providing fish. In addition, we would like to thank Klöfkorn, R. for comments and linguistic corrections. This work was funded by the power company BKK, Miljødirektoratet, Norwegian Research Centre (NORCE), Norwegian Institute for Water Research (NIVA) and The Research Council of Norway (Project No.: 294742, Hydropower induced supersaturation in freshwaters: effects on ecosystems, mitigation and solutions).

Open Access This article is licensed under a Creative Commons Attribution 4.0 International License, which permits use, sharing, adaptation, distribution and reproduction in any medium or format, as long as you give appropriate credit to the original author(s) and the source, provide a link to the Creative Commons licence, and indicate if changes were made. The images or other third party material in this article are included in the article's Creative Commons licence, unless indicated otherwise in a credit line to the material. If material is not included in the article's Creative Commons licence and your intended use is not permitted by statutory regulation or exceeds the permitted use, you will need to obtain permission directly from the copyright holder. To view a copy of this licence, visit http://creativecommons.org/licenses/by/4.0/.

Funding Open Access funding provided by Norwegian Institute for Water Research.

\section{References}

Alderdice, D. F. \& J. O. T. Jensen, 1985. An explanation for the high-resistance of incubating salmonid eggs to atmospheric gas supersaturation of water. Aquaculture 49: 85-88.

Anon., 2018. The status for Norwegian Atlantic salmon populations in 2018 (in Norwegian). Report from the Norwegian Scientific Advisory Committee for Atlantic Salmon Management: $1-11$.
Antcliffe, B., L. E. Fidler \& I. K. Birtwell, 2002. Effects of dissolved gas supersaturation on the survival and condition of juvenile rainbow trout (Oncorhynchus mykiss) under static and dynamic exposure scenarios. Canadian Technical Report of Fish and Aquatic Science 2370: 1-70.

Backman, T. \& A. Evans, 2002. Gas bubble trauma incidence in adult salmonids in the Columbia River Basin. North American Journal of Fisheries Management 22: 579-584.

Barlaup, B. T., H. Rund, E. S. Normann, S. Stranzl, S. Mahlum \& K. W. Vollset, 2018. Out of sync: monitoring the time of sea entry of wild and hatchery salmon Salmo salar smolt using floating passive-integrated transponder antennae. Journal of Fish Biology 93: 455-464.

Bouck, G. R., 1980. Etiology of gas bubble disease. Transactions of the American Fisheries Society 109: 703-707.

Brosnan, I. G., D. W. Welch \& M. Jacobs Scott, 2016. Survival rates of out-migrating yearling Chinook salmon in the lower Columbia River and plume after exposure to gassupersaturated water. Journal of Aquatisc Animal Health 28: 240-251.

Canadian Council of Ministers of the Environment, 1999. Canadian water quality guidelines for the protection of aquatic life: dissolved gas supersaturation. Canadian Council of Ministers of the Environment, Winnipeg: 1-7.

Cao, L., Y. Li, R. An, W. Yuanming, K. Li \& K. Buchmann, 2019. Effects of water depth on GBD associated with total dissolved gas supersaturation in Chinese sucker (Myxocyprinus asiaticus) in upper Yangtze River. Scientific Reports 9: 1-8.

Dawley, E. M. \& W. J. Ebel, 1975. Effects of various concentrations of dissolved atmospheric gas on juvenile Chinook salmon and steelhead trout. Fishery Bulletin 73: 787-796.

Deng, Y., Cao, C., Liu, X., Yuan, Q., Feng, C., Shi, H., Yang, Y., \& Wu, Y., 2020. Effect of total dissolved gas supersaturation on the survival of bighead carp (Hypophthalmichthys bilis). Animals 10: 1-14.

Ebel, W. J., 1969. Supersaturation of nitrogen in the Columbia River and its effect on salmon and steelhead trout. Fishery Bulletin 68: 1-11.

Espmark, A. M., K. Hjelde \& G. Baeverfjord, 2010. Development of gas bubble disease in juvenile Atlantic salmon exposed to water supersaturated with oxygen. Aquaculture 306: 198-204.

Geist, D. R., T. J. Linley, V. Cullinan \& Z. Deng, 2013. The effects of total dissolved gas on Chum salmon fry survival, growth, gas bubble disease, and seawater tolerance. North American Journal of Fisheries Management 33: 200-215.

Heggberget, T. G., 1984. Effect of supersaturated water on fish in the River Nidelva, Southern-Norway. Journal of Fish Biology 24: 65-74.

Henry, W., 1803. Experiments on the quantity of gases absorbed by water, at different temperatures, and under different pressures. The Royal Society 93: 29-274.

Holm, S., 1979. A simple sequentially rejective multiple test procedure. Scandinavian Journal of Statistics 6: 65-70.

Hutchings, J. A., W. R. Ardren, B. T. Barlaup, E. Bergman, K. D. Clarke, L. A. Greenberg, C. Lake, J. Piironen, P. Sirois, L. E. Sundt-Hansen \& D. J. Fraser, 2019. Life-history variability and conservation status of landlocked Atlantic salmon: an overview. Canadian Journal of Fisheries and Aquatic Sciences 76: 1697-1708. 
Ji, Q., S. Xue, Q. Yuan, Y. Yuan, Y. Wang, R. Liang, J. Feng, K. Li \& R. Li, 2019. The tolerance characteristics of resident fish in the upper yangtze river under varying gas supersaturation. International Journal of Environmental Research and Public Health 16: 1-13.

Kaplan, E. L. \& P. Meier, 1958. Nonparametric estimation from incomplete observations. Journal of the American Statistical Association 53: 457-481.

Krise, W. F. \& J. W. Meade, 1988. Effects of low-level gas supersaturation on lake trout (Salvelinus namaycush). Canadian Journal of Fisheries and Aquatic Sciences 45: 666-674.

Krise, W. F. \& R. L. Herman, 1991. Resistance of underyearling and yearling Atlantic salmon and lake trout to supersaturation with air. Journal of Aquatic Animal Health 3: 248-253.

Kristensen, T., B. O. Rosseland, A. Kiessling, B. Djordevic \& J. C. Massabau, 2010. Lack of arterial $\mathrm{PO}_{2}$ downregulation in Atlantic salmon (Salmo salar L.) during long-term normoxia and hyperoxia. Fish Physiology and Biochemistry 36: 1087-1095.

MacCrimmon, H. R. \& B. L. Gots, 1979. World distribution of Atlantic salmon, Salmo salar. Journal of the Fisheries Research Board of Canada 36: 422-457.

Marking, L. L., 1987. Gas Supersaturation in Fisheries: Causes, Concerns, and Cures. Fish and Wildlife Service, La Crosse: $1-10$.

Meekin, T. K. \& B. K. Turner, 1974. Tolerance of salmonid eggs, juveniles, and squawfish to super-saturated nitrogen. Washington Department of Fisheries Technical Report 12: 78-126.

Mesa, M. G., L. K. Weiland \& A. G. Maule, 2000. Progression and severity of gas bubble trauma in juvenile salmonids. Transactions of the American Fisheries Society 129: 174-185.

Mills, K. E., Pershing, A. J., Sheehan, T. F., \& Mountain, D., 2013. Climate and ecosystem linkages explain widespread declines in North American Atlantic salmon populations. Global Change Biology 19: 3046-3061.

Nebeker, A. V., 1976. Survival of daphnia, crayfish, and stoneflies in air-supersaturated water. Journal of the Fisheries Research Board of Canada 33: 1208-1212.

Nebeker, A. V., G. R. Bouck \& D. G. Stevens, 1976. Carbon dioxide and oxygen-nitrogen ratios as factors affecting salmon survival in air-supersaturated water. Transactions of the American Fisheries Society 105: 425-429.

Nebeker, A. V., F. D. Baker \& S. L. Weitz, 1981. Survival and adult emergence of aquatic insects in air-supersaturated water. Journal of Freshwater Ecology 1: 243-250.

Newcomb, T. W., 1974. Changes in blood-chemistry of juvenile steelhead trout, Salmo Gairdneri, following sublethal exposure to nitrogen supersaturation. Journal of the Fisheries Research Board of Canada 31: 1953-1957.

Pleizier, N. K., C. Nelson, S. J. Cooke \& C. J. Brauner, 2020. Understanding gas bubble trauma in an era of hydropower expansion: how do fish compensate at depth? Canadian Journal of Fisheries and Aquatic Sciences 77: 556-563.

Pulg, U., K. W. Vollset, G. Velle \& S. Stranzl, 2016. First observations of saturopeaking: characteristics and implications. Science of the Total Environment 573: 1615-1621.
Pulg, U., S. Stranzl, B. Wagner, P. Floedl \& C. Hauer, 2020. Gasübersättigung in Flüssen? Messung, Ursachen und Auswirkungen-Ein internationales Forschungsprojekt untersucht Verbreitung und Umwelteffekte. Österr Wasser- und Abfallw 72: 142-148.

Schiewe, M. H., 1974. Influence of dissolved atmospheric gas on swimming performance of juvenile Chinook salmon. Transactions of the American Fisheries Society 103: 717-721.

Schisler, G. J., E. P. Bergersen \& P. G. Walker, 1999. Evaluation of chronic gas supersaturation on growth, morbidity, and mortality of fingerling rainbow trout infected with Myxobolus cerebralis. North American Journal of Aquaculture 61: 175-183.

Shrimpton, J. M., D. J. Randal \& L. E. Fidler, 1990. Factors affecting swim bladder volume in rainbow-trout (Oncorhynchus Mykiss) held in gas supersaturated water. Canadian Journal of Zoology-Revue Canadienne De Zoologie 68: 962-968.

USEPA (U.S. Environmental Protection Agency), 1976. Quality Criteria for Water. Government Printing Offic, Washington.

Wang, Y., K. Li, J. Li, R. Li \& Y. Deng, 2015. Tolerance and avoidance characteristics of Prenant's schizothoracin Schizothorax prenantito total dissolved gas supersaturated water. North American Journal of Fisheries Management 35: 827-834.

Weiss, R. F., 1970. The solubility of nitrogen, oxygen and argon in water and seawater. Deep Sea Research and Oceanographic Abstracts 17: 721-735.

Weitkamp, D. E., 1976. Dissolved gas supersaturation: live cage bioassays at Rock Island Dam. In Fickeisen, D. H. \& M. J. Schneider (eds), Gas Bubble Desease. Energy Research and Development Administration, Technical Information Center, Richland: 24-36.

Weitkamp, D. E., 2000. Total dissolved gas supersaturation in the natural river environment. Parametrix Inc., Kirkland, Washington: 1-19.

Weitkamp, D. E., 2008. Total dissolved gas supersaturation biological effects, review of literature 1980-2007. Parametrix Inc., Bellevue, Washington: 1-60.

Weitkamp, D. E. \& M. Katz, 1980. A review of dissolved gas supersaturation literature. Transactions of the American Fisheries Society 109: 659-702.

Weitkamp, D. E. \& R. D. Sullivan, 2003. Behavior of resident fish relative to total dissolved gas supersaturation in the Lower Clark Fork River. Transactions of the American Fisheries Society 132: 856-864.

Wright, R. F., R. M. Couture, A. B. Christiansen, J. L. Guerrero, $\varnothing$. Kaste \& B. Barlaup, 2016. Effects of multiple stresses hydropower, acid deposition and climate change on water chemistry and salmon populations in the River Otra, Norway. The Science of the Total Environment 574: 128-138.

Xue, S., Y. Wang, R. Liang, K. Li \& R. Li, 2019. Effects of total dissolved gas supersaturation in fish of different sizes and species. International Journal of Environmental Research and Public Health 16: 1-12.

Publisher's Note Springer Nature remains neutral with regard to jurisdictional claims in published maps and institutional affiliations. 